\title{
Recycling of Local Qatar's Steel Slag and Gravel Deposits in Road Construction
}

Ramzi Taha*,Okan Sirin and Husam Sadek

Department of Civil and Architectural Engineering College of Engineering Qatar University, Qatar

*Corresponding author: Ramzi Taha, Department of Civil and Architectural Engineering College of Engineering, Qatar University, Qatar, Tel: +97-444034172; E-mail: ramzitaha@qu.edu.qa

Received date: December 04, 2014, Accepted date: December 30, 2014, Published date: December 31, 2014

Copyright: (c) 2014 Taha R, et al. This is an open-access article distributed under the terms of the Creative Commons Attribution License, which permits unrestricted use, distribution, and reproduction in any medium, provided the original author and source are credited.

\begin{abstract}
Every year, the State of Qatar generates about 400,000 tons of steel slag and another 500,000 tons of gravel as a result of steel manufacturing and washing sand, respectively. The two materials (by-products) are not fully utilized to their best market values. At the same time, infrastructural renewal will take place in Qatar over the next ten years, and there will be a greater demand for aggregates and other construction materials as the country suffers from the availability of good aggregates. This paper presents results obtained on the use of steel slag, gravel and gabbro (control) in hot mix asphalt concrete (HMAC) paving mixtures and road bases and sub-bases. Tests were conducted in accordance with Qatar Construction Specifications (QCS-2010) and results were compared with QCS requirements for aggregates used in these applications. Based on the data obtained in this work, steel slag and gravel aggregates have a promising potential to be used in hot mix asphalt concrete paving mixtures on Qatar's roads, whether in asphalt base and asphalt wearing courses or as unbound aggregates in the base and sub-base pavement structure.
\end{abstract}

Keywords: Steel slag; Gravel; By-products; Asphalt concrete; Subbase; Qatar

\section{Introduction}

In the State of Qatar, steel slag, a by-product of steel manufacturing, is generated in large quantities. In fact, it is estimated that more than 400,000 tons ( 1 ton $=1016.05 \mathrm{~kg}$ ) of steel slag are generated annually and they are not efficiently utilized in construction [1]. The disposal of such quantities poses a great burden on Qatar's Steel. In addition, gravel, resulting from washing sand, is also produced at more than 500,000 tons per year in Qatar [1]. Simultaneously, infrastructural renewal (roads, bridges, metro, railways, new airport, deep-water seaport, hotels, stadiums, etc.) will take place in the State of Qatar over the next ten years and there will be a greater demand for aggregates and other construction materials. Qatar suffers from the availability of good aggregates that could be utilized in roads, parking, buildings and other construction. In fact, Qatar imports most of its aggregates needs from neighboring countries. Thus, our environmental responsibilities and potential economic benefits that might be realized dictate that steel slag and other discarded materials should be utilized in the construction sector.

Research is thus needed to promote and investigate, where possible, the recycling of steel slag and gravel deposits in Qatar's construction industry. This paper presents results obtained on the use of steel slag, gravel and gabbro in hot mix asphalt concrete (HMAC) paving mixtures in addition to road bases and sub-bases. All tests were conducted in accordance with Qatar Construction Specifications (QCS-2010).

\section{Literature Review}

Waste is an unavoidable by-product of most human activities. Economic growth and rising living standards in many parts of the world have led to an increase in the quantities of generated wastes.
Steel slag, a by-product of steel manufacturing, is no exception. It is produced either from the conversion of iron to steel in a Basic Oxygen Furnace (BOF) or by the melting of scarp to make steel in the Electric Arc Furnace (EAF). The slag is produced as a molten liquid melt and it is a complex solution of silicates and oxides that solidifies upon cooling. The American Society for Testing and Materials (ASTM) defines steel slag as "a non-metallic product, consisting essentially of calcium silicates and ferrites combined with fused oxides of iron, aluminium, manganese, calcium and magnesium that are developed simultaneously with steel in basic oxygen, electric furnace, or open hearth furnaces [2]."

Chemical composition, mechanical and environmental properties in addition to some undesirable characteristics of steel slag were presented in a previous work [1].

\section{Hot mix asphalt concrete}

Steel slag has been successfully used in asphalt paving mixtures in the United States, Canada, Europe and Japan [3,4,6-9]. It is used as an aggregate in hot mix asphalt wearing courses and surface treatments, including chip seals. Positive properties of steel slag aggregates, when used in asphalt paving, include high stability, excellent stripping and skid resistance, and resistance to rutting. Proper processing of steel slag and special quality control procedures should be in-place when selecting steel slag for use in asphalt paving. ASTM D5106 [2] is the Standard Specification for Steel Slag Aggregates for Bituminous Paving Mixtures. BS 4987: Part I [10] specifies the use of steel slag as one of the aggregate types in coated macadam for roads and other paved areas.

However, the literature $[5,6]$ cautions against using $100 \%$ steel slag aggregate in asphalt paving as such hot mix asphalt concrete mixes might be susceptible to high void space and bulking problems due to the angularity of the steel slag. Hot mix asphalt with $100 \%$ steel aggregates might be prone to over asphalting during production, 
Page 2 of 7

which could lead to subsequent flushing during in-service traffic compaction. Thus, steel slag aggregates' use in asphalt paving should be restricted to either the fine or coarse aggregate fraction, but not both, for better aggregate interlocking, lower void space and higher frictional resistance. This can be achieved by blending the coarse or fine steel slag aggregates with conventional natural materials such as gravels (more rounded) for better compatibility of the final asphalt mix.

\section{Granular bases and sub-bases}

Steel slag aggregates can be used in the construction of unpaved parking lots, as railroad ballast, as a shoulder material, and also in the construction of berms and embankment. Experience in many countries including the United States, Belgium, Japan, The Netherlands, Germany, and Saudi Arabia [4,5,11-13] has referred that steel slag aggregates, when properly selected, processed, aged, and tested, can be used as granular base for roads in above-grade applications. Positive properties of steel slag include very high stability and good soundness.

S. Aiban [12] examined the use of steel slag aggregates generated in Saudi Arabia in road bases and he asserted that "laboratory and field data have shown the superior performance of steel slag aggregates over the locally available calcareous sediments. The resulting California Bearing Ratio values are doubled and the water sensitivity is much less when using steel slag aggregates instead of the local calcareous material."

Though, the literature $[5,14]$ cautions against using steel slag aggregates in confined applications, such as backfill behind structures, granular bases and sub-bases confined by curb and gutter, and trenches. This has primarily to do with the potential for volumetric expansion of steel slag due to free lime hydration. Also, concerns have risen over the formation of tufa-like precipitates that might clog subdrains and drain outlets $[11,15]$.

\section{Objective of the Study}

The main objective of this paper is to present the results obtained on the feasibility of using steel slag, gravel and gabbro in hot mix asphalt concrete mixtures and in road base and sub-bases according to Qatar Construction Specifications (QCS-2010). The conventional aggregate "gabbro" was used as the control mixture.

\section{Experimental Program}

Steel slag, gabbro and gravel aggregates used in the study were supplied by Slag Aggregates Producer (SAP) from their plant in Mesaieed City in Qatar. A total of 15 bags were delivered to the asphalt laboratory at Qatar University (QU), including 6 tons of slag, 2 tons of gabbro and 2 tons of gravel of different sizes. Gabbro is an igneous rock that has been used in road construction for a long time in this region. The steel slag aggregate was aged at the SAP Plant between 1 and 8 years. SAP delivered all three aggregates in compliance with QCS gradations' requirements.

\section{Hot mix asphalt concrete}

All hot mix asphalt concrete paving mixtures were designed using the Marshall Mix design method (ASTM D6926 and ASTM D6927), which is the standard method specified for use in Qatar. The design of an asphalt concrete mixture includes:
1. Selection of best aggregate blend.

2. Determination of the optimum asphalt content.

Finally, the mix should meet specifications' requirements and be economical at the same time.

A total of three aggregate types (steel slag, gravel and gabbro), supplied in different sizes, and were used in this study. Aggregate blend gradation was prepared to satisfy the gradations' requirements for an Asphaltic Concrete Wearing Course (SC-TYPE 1) in QCS-2010. Maximum aggregate size was $25 \mathrm{~mm}$. The blend gradation and specification limits are plotted in Figure 1.

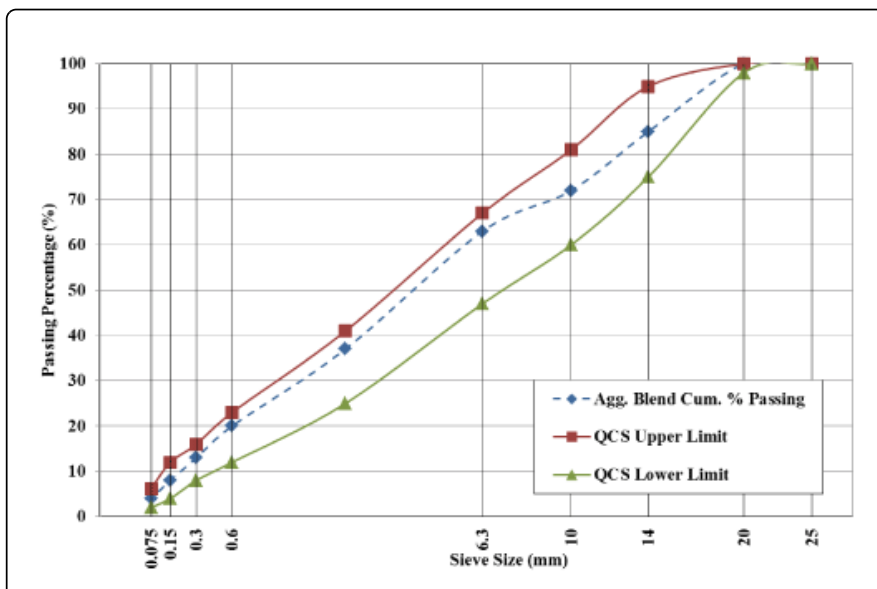

Figure 1: Design Gradation and QCS-2010 Limits.

A total of six different aggregate combinations were used to prepare asphalt mixtures in the laboratory. For the 50\% steel slag with 50\% gravel, $50 \%$ steel slag with $50 \%$ gabbro, and $50 \%$ gravel with $50 \%$ gabbro mixtures, the quantity of every aggregate size of the blend was divided by two. The conventional unmodified Pen 60/70 bitumen, obtained from the Woqod Company, was used to prepare all Marshall Mixes.

A $102 \mathrm{~mm}$ diameter by $64 \mathrm{~mm}$ high cylindrical bituminous mixture samples were prepared and compacted in the laboratory according to ASTM D6926. In order to determine the optimum asphalt content for each mix, a series of test samples was prepared for a range of asphalt contents (from 3 to $7 \%$ ) in $0.5 \%$ increments. Three replicate samples were prepared at each asphalt content. All samples were compacted using 75 blows on each side and designed for heavy traffic conditions.

\section{Road base and sub-base}

On the other hand, different sizes of aggregates were blended to meet the gradation of a sub-base course (Class C) as given in QCS-2010. The gradation of the sub-base material used in this project along with the upper and lower \% passing requirements given in QCS-2010 can be seen in Table 1.

For this purpose, different amounts of water were added to subbase mixes composed of $100 \%$ steel slag, $100 \%$ gabbro and $100 \%$ gravel to determine the optimum moisture content (OMC) using the modified Proctor compaction test (ASTM D1557-12). Samples were compacted using 25 blows in 5 layers using a $44.48 \mathrm{~N}$ rammer dropped from a distance of $457.2 \mathrm{~mm}$. Corrected moisture contents were determined after drying samples at an oven temperature of $110 \pm 5^{\circ} \mathrm{C}$ for 24 hours. 
Citation: Ramzi Taha,Okan Sirin and Husam Sadek (2014) Recycling of Local Qatar's Steel Slag and Gravel Deposits in Road Construction. Int J Waste Resources 4: 167. doi:10.4172/2252-5211.1000167

Page 3 of 7

\begin{tabular}{|c|c|c|c|}
\hline B.S. Sieve Size & Cumulative Passing (\%) & \multicolumn{2}{|c|}{ QCS 2010 Limits } \\
\hline $25 \mathrm{~mm}$ & 100 & 100 & 100 \\
\hline $20.0 \mathrm{~mm}$ & 95 & 90 & 100 \\
\hline $10.0 \mathrm{~mm}$ & 67 & 50 & 85 \\
\hline $5.0 \mathrm{~mm}$ & 50 & 35 & 65 \\
\hline $2.36 \mathrm{~mm}$ & 37 & 25 & 50 \\
\hline $425 \mu \mathrm{m}$ & 22 & 15 & 30 \\
\hline $75 \mu \mathrm{m}$ & 10 & 5 & 15 \\
\hline
\end{tabular}

Table 1: Gradation of sub-base aggregate blend.

Then, samples were compacted manually by 62 blows in 5 layers using a $4.5 \mathrm{~kg}$ rammer at the OMC in accordance with BS 1377-4: 1990. Compacted samples were soaked in water for 96 hours before the California Bearing Ratio (CBR) test is conducted. Two replicate samples were used for each aggregate type to determine the CBR values.

\section{Discussion of Results}

\section{Physical properties}

First, physical properties of the steel slag, gabbro and gravel aggregates were investigated. All tests were conducted in accordance with ASTM standards. The steel slag aggregate shown in Figure 2 has the following general properties:

- Physical state: solid.

- Color: dark gray.

- Shape and characteristics: very rough and porous surface with high angularity.

- Odor: odorless.

- Solubility: insoluble in water, oil and solvents.

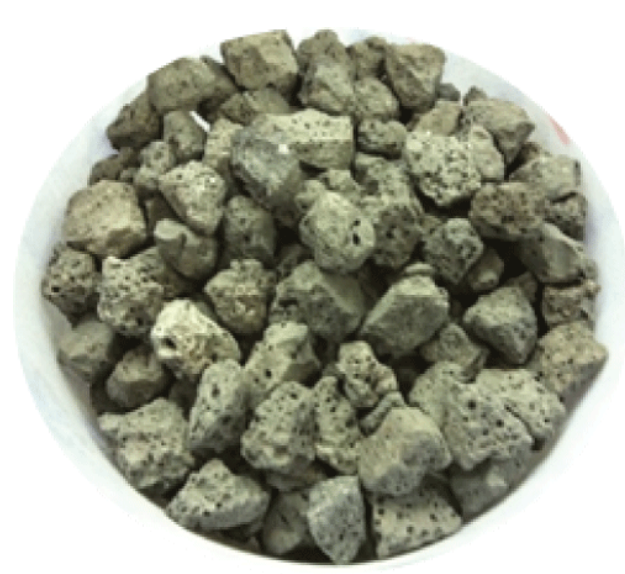

Figure 2: Steel slag aggregates.

The steel slag, gravel and gabbro aggregates failed the liquid limit and plastic limit tests (i.e. the aggregates are non-plastic). In addition, the bulk, saturated surface-dry (SSD) and apparent (APP) specific gravity tests were performed on the steel slag, gravel and gabbro aggregates. Table 2 indicates that all specific gravity values for steel slag (fine and coarse) are greater than those of gabbro and gravel.

\begin{tabular}{|c|c|c|c|}
\hline Specific gravity & Steel Slag & Gabbro & Gravel \\
\hline Bulk SG for coarse aggregates & 3.39 & 2.95 & 2.62 \\
\hline Bulk SG for fine aggregates & 3.54 & 2.86 & 2.59 \\
\hline SSD SG1 for coarse aggregates & 3.43 & 2.96 & 2.64 \\
\hline SSD SG for fine aggregates & 3.58 & 2.9 & 2.64 \\
\hline APP SG2 for coarse aggregates & 3.52 & 2.98 & 2.69 \\
\hline APP SG for fine aggregates & 3.69 & 2.98 & 2.72 \\
\hline
\end{tabular}

Table 2: Specific gravity results of steel slag, gabbro and gravel. ( ${ }^{1}$ SSD: Saturated Surface Dry; ${ }^{2}$ APP: Apparent Specific Gravity).

Then, the unit weight values for all aggregate types used in this study were determined as shown in Table 3. As a result of its high specific gravity, the steel slag had the highest unit weight compared to other aggregate types. Also, the average absorption values for the steel slag aggregates were $1.06 \%$ for coarse and $1.13 \%$ for fine aggregates (Table 3). These results are acceptable according to the QCS-2010specifications. However, the coarse aggregates of gabbro had the lowest water absorption percentage and this is due to the strong inert structure of gabbro aggregates that have the least voids.

On the other hand, the toughness results of steel slag, gabbro and gravel were obtained from the Los Angeles abrasion Test. The average L.A. abrasion for steel slag was $14.9 \%$ as presented in Table 3. This was less than the $25-30 \%$ limit established for coarse aggregates and it was less than that of gravel deposits $(22.7 \%)$, but more than that of gabbro $(8.1 \%)$. Table 3 presents also the sand equivalent results for the steel slag, gravel and gabbro aggregates. All samples had high percentage values, which were above the minimum threshold specified by the QCS-2010 specifications' requirements. Gabbro had the highest sand equivalent value.

To determine the flakiness and elongation indices, $2 \mathrm{~kg}$ of each aggregate type was tested according to BS 812: Sections 105.1 and 105.2, respectively. The results presented in Table 3 alluded that all aggregate types are below the acceptable limit. However, gravel had the highest flakiness and elongation indices. In the soundness test, two sizes from coarse and fine aggregates were tested and the results are presented in Table 3. The data indicate that steel slag had the lowest soundness value, while gravel had the highest one. The soundness value for fine gravel aggregates (30.3\%) failed the QCS-2010 requirement of $\leq 18 \%$ for asphalt works.

In general, the steel slag aggregates and gravel test results presented in Tables 2 and 3 were comparable to typical values reported in the literature, and they met the QCS-2010 requirements. 
Citation: Ramzi Taha,Okan Sirin and Husam Sadek (2014) Recycling of Local Qatar's Steel Slag and Gravel Deposits in Road Construction. Int J Waste Resources 4: 167. doi:10.4172/2252-5211.1000167

Page 4 of 7

\begin{tabular}{|c|c|c|c|c|c|c|}
\hline \multirow[b]{2}{*}{ Property } & \multirow[b]{2}{*}{ ASTM Standard } & \multicolumn{2}{|c|}{ QCS-2010 Specifications } & \multirow[b]{2}{*}{ Steel Slag } & \multirow[b]{2}{*}{ Gabbro } & \multirow[b]{2}{*}{ Gravel } \\
\hline & & $\begin{array}{l}\text { Unbound } \\
\text { Materials }\end{array}$ & $\begin{array}{l}\text { Asphalt } \\
\text { Works }\end{array}$ & & & \\
\hline Unit weight, $\left(\mathrm{kg} / \mathrm{m}^{3}\right)$ & $\mathrm{C} 29$ & - & - & 2595 & 2169 & 2338 \\
\hline Water absorption for coarse aggregates, $(\%)$ & C128 & - & $\leq 1.5$ & 1.06 & 0.34 & 1.12 \\
\hline Water absorption for fine aggregates, $(\%)$ & C128 & - & - & 1.13 & 1.38 & 1.93 \\
\hline L.A. abrasion, (\%) & C131/C535 & $\leq 40$ & $\leq 25-30$ & 14.9 & 8.1 & 22.7 \\
\hline Sand equivalent for fine aggregates, $(\%)$ & D2419 & $\geq 25$ & $>30$ & 41 & 47 & 33 \\
\hline Flakiness index, (\%) & BS 812 & $\leq 35$ & $\leq 25-30$ & 1 & 8 & 17 \\
\hline Elongation index, (\%) & BS 812 & $\leq 40$ & $\leq 25$ & 13 & 24 & 26 \\
\hline Soundness for coarse aggregates, (\%) & C88 & $\leq 20$ & $\leq 10-15$ & 1 & 2 & 7 \\
\hline Soundness for fine aggregates, (\%) & $\mathrm{C} 88$ & - & $\leq 18$ & 4.2 & 16 & 30.3 \\
\hline
\end{tabular}

Table 3: Physical properties of steel slag, gabbro and gravel.

\section{Radiological properties}

A total of 11 samples of asphalt concrete cylinders made of $100 \%$ steel slag, were received by the Nuclear Laboratory at QU. Samples were measured directly in plastic bags on a HPGe detector in order to determine which radionuclides had activity concentrations significantly higher than the background level. Each sample was assessed for the following naturally occurring radionuclides from the Uranium and Thorium decay series, as well as ${ }^{40} \mathrm{~K}$.

Each sample was prepared directly into a $200 \mathrm{ml}$ PET container, filling the container as much as possible. No measures were taken to further homogenize the samples. The samples were measured directly on a $50 \%$ p-type HPGe detector for a time period of between two hours and one day, depending on the activity level in the sample. This detector has been efficiency calibrated using a radioactivity standard from NPL, UK. Spectrum acquisition and analysis was carried out using Ortec GammaVision software. All activities were decay corrected to the actual measurement date. In order to correct for disparities between the sample matrix and standard matrix, a postadjustment geometry correction of the measurement result was performed using efficiency transfer methods. For this geometry correction, slag is assumed to mainly be composed of $\mathrm{CaSiO}_{3}$, while limestone and river stone is assumed to be composed mainly of $\mathrm{CaMg}\left(\mathrm{CO}_{3}\right)_{2}$. Gravel is assumed to be composed of $50 \% \mathrm{CaSiO}_{3}$ and $50 \% \mathrm{CaMg}\left(\mathrm{CO}_{3}\right)_{2}$, while Gabbro is simulated as basalt. In practice, this chemical composition will have only a slight impact on the final measurement results compared to the effect of the sample density and volume.

For the natural decay series, secular radioactive equilibrium is assumed between ${ }^{226} \mathrm{Ra}$ and daughters as well as ${ }^{228} \mathrm{Ra}$ and daughters. Often, ${ }^{228} \mathrm{Ra}$ can further be assumed to be in equilibrium with ${ }^{232} \mathrm{Th}$. Activity concentrations have been calculated as follows:

- ${ }^{40} \mathrm{~K}$ - directly from $1460 \mathrm{keV}$ peak

- $\quad{ }^{226} \mathrm{Ra}$ - from daughter nuclides ${ }^{214} \mathrm{~Pb}$ and ${ }^{214} \mathrm{Bi}$

- $\quad{ }^{228} \mathrm{Ra}$ - from daughter nuclide ${ }^{228} \mathrm{Ac}$

- $\quad{ }^{228} \mathrm{Th}$ - from daughter nuclides ${ }^{208} \mathrm{Tl}$ and ${ }^{212} \mathrm{~Pb}$

- ${ }^{238} \mathrm{U}$ - from daughter nuclide ${ }^{234} \mathrm{mPa}$
Table 4 below presents the nuclides of interest and their calculated activity concentrations for raw materials and asphalt concrete made of $100 \%$ steel slag aggregates. In the cases where the activity concentration of the sample falls below the minimum detectable activity (MDA) of the measurement, the result is reported as less than $(<)$ a value. MDA's and uncertainties are reported at a 95\% confidence level.

\begin{tabular}{|c|c|c|c|c|c|}
\hline \multirow{2}{*}{$\begin{array}{c}\text { Sample } \\
\text { Type }\end{array}$} & \multicolumn{5}{|c|}{ Activity Concentration $(\mathrm{Bq} / \mathrm{kg})$} \\
\hline & ${ }^{40} \mathbf{K}$ & ${ }^{226} \mathrm{Ra}$ & ${ }^{228} \mathrm{Ra}$ & ${ }^{228} \mathrm{Th}$ & ${ }^{238} \mathbf{U}$ \\
\hline $\begin{array}{l}\text { Crushed } \\
\text { slag 3/4" }\end{array}$ & $23 \pm 14$ & $252 \pm 25$ & $144 \pm 15$ & $151 \pm 15$ & $290 \pm 140$ \\
\hline Slag raw & $<21$ & $212 \pm 22$ & $167 \pm 18$ & $166 \pm 17$ & $270 \pm 150$ \\
\hline $\begin{array}{c}\text { River stone } \\
\text { raw }\end{array}$ & $98 \pm 10$ & $8.0 \pm 0.8$ & $4.8 \pm 0.8$ & $5.1 \pm 0.5$ & $<36$ \\
\hline $\begin{array}{c}\text { Gravel } \\
5 \mathrm{~mm}\end{array}$ & $244 \pm 27$ & $15.9 \pm 1.6$ & $8.3 \pm 2.0$ & $9.2 \pm 1.1$ & $<95$ \\
\hline $\begin{array}{l}\text { Limestone } \\
5 \mathrm{~mm}\end{array}$ & $12.5 \pm 2.6$ & $4.7 \pm 0.5$ & $2.2 \pm 0.8$ & $2.3 \pm 0.4$ & $<28$ \\
\hline $\begin{array}{c}\text { Gabbro } \\
7 \mathrm{~mm}\end{array}$ & $<7.7$ & $<1.5$ & $<2.6$ & $<1.6$ & $<56$ \\
\hline Slag $5 \mathrm{~mm}$ & $22 \pm 11$ & $237 \pm 18$ & $152 \pm 16$ & $158 \pm 16$ & $300 \pm 120$ \\
\hline $\begin{array}{c}\text { Slag } \\
\text { powder } \\
0-1 \mathrm{~mm}\end{array}$ & $62 \pm 15$ & $167 \pm 17$ & $128 \pm 15$ & $136 \pm 14$ & $350 \pm 150$ \\
\hline $\begin{array}{c}\text { Slag } \\
\text { powder } \\
0-5 \mathrm{~mm}\end{array}$ & $36 \pm 12$ & $218 \pm 16$ & $156 \pm 16$ & $172 \pm 17$ & $210 \pm 110$ \\
\hline $\begin{array}{c}\text { Slag raw } \\
\text { (new) }\end{array}$ & $<17$ & $184 \pm 19$ & $182 \pm 19$ & $195 \pm 20$ & $270 \pm 150$ \\
\hline $\begin{array}{l}\text { Slag raw } \\
\text { (old) }\end{array}$ & $25 \pm 12$ & $213 \pm 22$ & $156 \pm 16$ & $171 \pm 17$ & $280 \pm 100$ \\
\hline
\end{tabular}




\begin{tabular}{|c|c|c|c|c|c|}
\hline $\begin{array}{c}\text { Asphalt } \\
\text { concrete }\end{array}$ & $<8.0$ & $182 \pm 18$ & $175 \pm 23$ & $195 \pm 20$ & $200 \pm 90$ \\
\hline
\end{tabular}

Table 4: Nuclides' activity concentration results.

Table 5 presents the activity concentration indices for different combinations of gabbro/gravel/slag compared against standard values (H1and H2) recommended by the Qatari Ministry of Environment (MOE). These standard values were specified by MOE-Laboratories and Standardization Affairs as part of a memorandum issued to a local materials company operating in Qatar that allowed the use of a maximum $20 \%$ steel slag in certain asphalt concrete and Portland cement concrete road applications. The memorandum specifies other requirements as part of the whole package. $\mathrm{H} 1$ is the activity concentration index standard for the use of steel slag in certain asphalt concrete and Portland cement concrete road applications close to populated and residential areas, while $\mathrm{H} 2$ is the activity concentration index standard for the use of steel slag in certain asphalt concrete road applications for freeways and roads outside Doha, Capital of Qatar. It should be noted that all activity concentration indices were calculated based on the values measured in the Nuclear Laboratory at Qatar University and presented earlier in Table 4.

\begin{tabular}{|c|c|c|c|}
\hline Mix Type & H1 & H2 & MOE Standard \\
\hline G20-100 (100\% Gabbro) & 0.0205 & 0.0083 & $\leq 1.0$ \\
\hline S20-100 (100\% Slag) & 1.7706 & 0.7317 & $\leq 1.0$ \\
\hline GL20-100 (100\% Gravel) & 0.1758 & 0.0698 & $\leq 1.0$ \\
\hline S20-75 (75\% Slag+ 25\% Gabbro) & 1.3333 & 0.5508 & $\leq 1.0$ \\
\hline GL20-75 (75\% Gravel+ 25\% Gabbro) & 0.1369 & 0.0544 & $\leq 1.0$ \\
\hline S20-50 (50\% Slag+50\% Gabbro) & 0.8956 & 0.37 & $\leq 1.0$ \\
\hline GL20-50 (50\% Gravel+50\% Gabbro) & 0.0982 & 0.039 & $\leq 1.0$ \\
\hline S20-25 (25\% Slag+75\% Gabbro) & 0.458 & 0.1891 & $\leq 1.0$ \\
\hline GL20-25 (25\% Gravel+ 75\% Gabbro) & 0.0594 & 0.0236 & $\leq 1.0$ \\
\hline Asphalt Concrete (100\% Slag) & 1.4843 & 0.611 & $\leq 1.0$ \\
\hline Portland Cement Concrete (100\% Slag) & 1.2163 & 0.4992 & $\leq 1.0$ \\
\hline
\end{tabular}

Table 5: Activity concentration indices for different gabbro/gravel/slag mixtures.

Note:

$H_{1}=\frac{C T H}{200}+\frac{C R a}{300}+\frac{C K}{3000}+\ldots$

$H_{2}=\frac{C_{T H}}{500}+\frac{C_{R a}}{700}+\frac{C_{K}}{8000}+\frac{C C s}{2000}+\ldots$

$\mathrm{C}_{\mathrm{TH}}=$ Activity concentration value of ${ }^{232} \mathrm{Th}$ (assumed in equilibrium with ${ }^{228} \mathrm{Ra}$ ) in $\mathrm{Bq} / \mathrm{kg}$

$\mathrm{C}_{\mathrm{Ra}}=$ Activity concentration value of ${ }^{226} \mathrm{Ra}$ in $\mathrm{Bq} / \mathrm{kg}$

$\mathrm{C}_{\mathrm{k}}=$ Activity concentration value of ${ }^{40} \mathrm{~K}$ in $\mathrm{Bq} / \mathrm{kg}$

$\mathrm{C}_{\mathrm{Cs}}=$ Activity concentration value of ${ }^{137} \mathrm{Cs}$ in $\mathrm{Bq} / \mathrm{kg}$

Table 5 indicates that the use of higher percentages of steel slag, beyond the $20 \%$ specified by MOE, will easily meet the $\mathrm{H} 2$ requirement of $\leq 1.0$ for asphalt concrete road applications such as freeways and roads outside Doha. Even for steel slag usage in certain asphalt concrete road applications close to populated and residential areas, it will be possible to meet the $\mathrm{H} 1$ requirement of $\leq 1.0$ if other mix design requirements and MOE recommendations are met.

\section{Hot mix asphalt concrete results}

After the samples were compacted using the Marshall compactor, the bulk specific gravity and density of specimens were determined in accordance with ASTM D2726. Prior to the stability and flow tests, compacted asphalt samples were immersed in a water bath at $60^{\circ} \mathrm{C}$ for 30-40 minutes. All samples were tested in the Marshall Test Apparatus.

Using the graphs of air voids (\%AV) vs. asphalt content (\%AC), voids in mineral aggregate (\%VMA) vs. \%AC and stability vs. \%AC, the optimum asphalt content (OAC) can be determined by averaging the \% AC determined for each of three parameters. Examples of these graphs are shown in Figures 3 and 4.

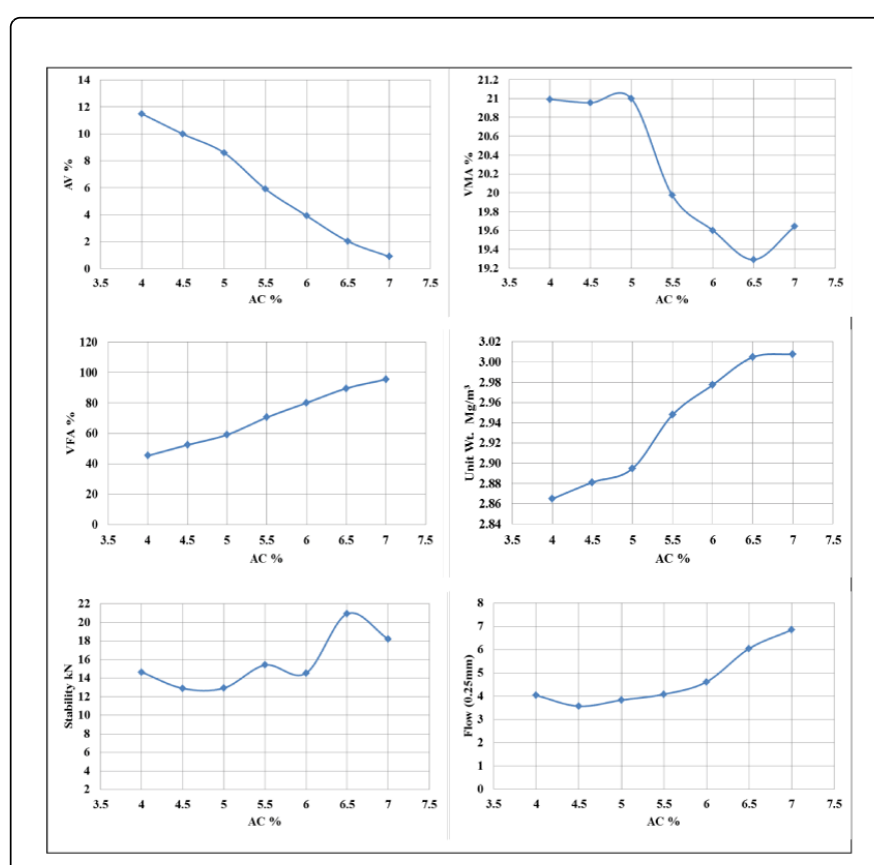

Figure 3: Marshall Test graphs for $100 \%$ steel slag asphalt concrete mixture.

After determining the OAC for each mixture, three samples were prepared at this optimum and mixture properties were compared to the mix design criteria given in Table 6.

As presented in Table 6, the 100\% steel slag aggregate mixture had the highest optimum asphalt content of $6.39 \%$, which is attributed to the high void space and bulking of the material. However, mixtures prepared using $50 \%$ steel slag and $50 \%$ gabbro or gravel aggregates produced better stability, lower flow, and lower optimum asphalt content. 
Page 6 of 7

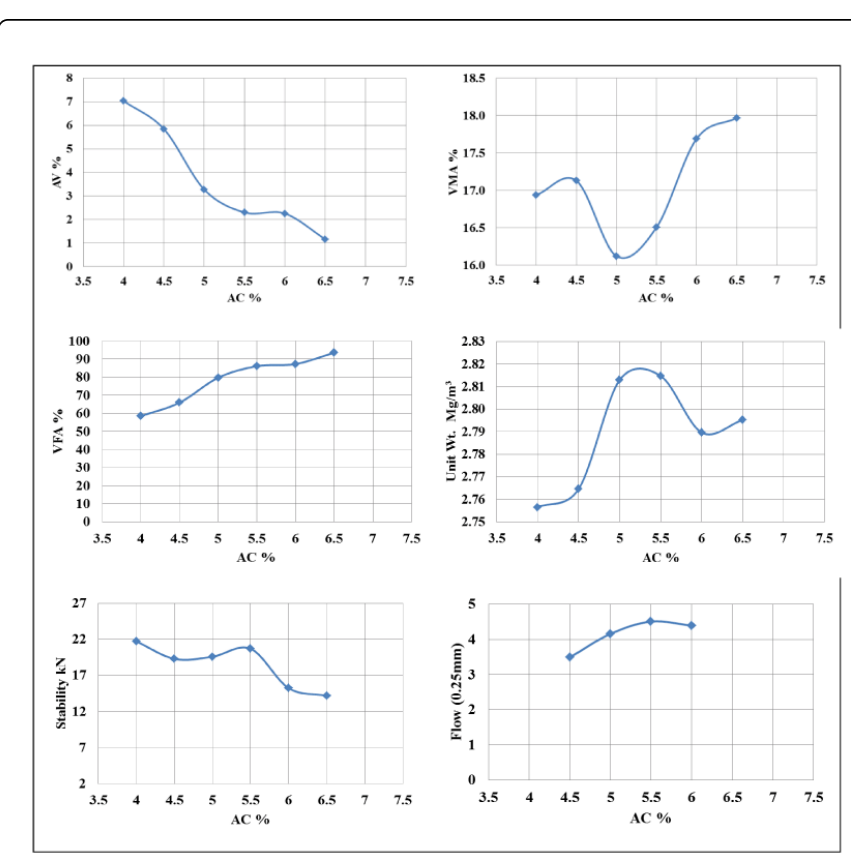

Figure 4: Marshall test graphs for $50 \%$ steel slag $+50 \%$ gabbro asphalt concrete mixture.

In general, Table 6 indicates that all six mixtures have met stability, flow and Marshall Quotient/Stiffness criteria as specified in QCS-2010. VMA values for all mixtures, except for the $100 \%$ gravel aggregates mixture, were also satisfied. However, all mixtures resulted in lower air voids contents than that of a minimum value requirement of $5 \%$. All mixtures had higher VFA values than that of a maximum value requirement of $75 \%$. The most probable reason for this is the lack of sand in the mixtures. In this study, it was only attempted to maximize the use of steel slag and gravel aggregates in the mixtures. Aggregate gradations used were within the QCS-2010 lower and upper limits.

\section{Road base and sub-base results}

Optimum moisture content: The compaction curves for each aggregate type were established after a sufficient number of water contents were used. The relationship between the dry unit weight and water content for the three aggregates are shown in Figure 5.

\begin{tabular}{|c|c|c|c|c|c|c|c|c|}
\hline $\begin{array}{c}\text { Mix } \\
\text { Type }\end{array}$ & $\begin{array}{c}\text { Optimum } \\
\text { Asphalt } \\
\text { Content } \\
\text { (\%) }\end{array}$ & $\begin{array}{c}\text { Stability } \\
\text { (N) }\end{array}$ & $\begin{array}{c}\text { Flow } \\
(\mathbf{m m})\end{array}$ & $\begin{array}{c}\text { Marshall } \\
\text { Quotient/ } \\
\text { Stiffness, } \\
(\mathbf{k N / m m})\end{array}$ & $\begin{array}{c}\text { AV } \\
\mathbf{( \% )}\end{array}$ & $\begin{array}{c}\text { VMA } \\
\mathbf{( \% )}\end{array}$ & $\begin{array}{c}\text { VFA } \\
(\%)\end{array}$ & $\begin{array}{c}\text { Filler/ } \\
\text { Asphalt } \\
\text { Ratio }\end{array}$ \\
\hline $\begin{array}{c}100 \% \\
\text { Slag }\end{array}$ & 6.39 & 22,080 & 3.53 & 6.25 & 2.67 & 19.5 & 86 & 0.63 \\
\hline $\begin{array}{c}100 \% \\
\text { Gravel }\end{array}$ & 5.4 & 15,550 & 3.1 & 5.02 & 2.13 & 13 & 83 & 0.74 \\
\hline $\begin{array}{c}100 \% \\
\text { Gabbro }\end{array}$ & 5.35 & 16,640 & 3.82 & 4.36 & 3.26 & 15.3 & 79 & 0.75 \\
\hline $\begin{array}{c}50 \% \\
\text { Slag + } \\
50 \% \\
\text { Gabbro }\end{array}$ & 5.19 & 23,880 & 3.02 & 7.91 & 2.68 & 16.1 & 83 & 0.77 \\
\hline
\end{tabular}

\begin{tabular}{|c|c|c|c|c|c|c|c|c|}
\hline $\begin{array}{c}50 \% \\
\text { Slag + } \\
50 \% \\
\text { Gravel }\end{array}$ & 5.22 & 22,200 & 2.75 & 8.07 & 2.96 & 16.5 & 82 & 0.77 \\
\hline $\begin{array}{c}50 \% \\
\text { Gravel + } \\
50 \% \\
\text { Gabbro }\end{array}$ & 5.08 & 22,900 & 3.07 & 7.46 & 2.1 & 13 & 84 & 0.79 \\
\hline $\begin{array}{c}\text { QCS-201 } \\
0(75 \\
\text { blows } \\
\text { compacti } \\
\text { on) }\end{array}$ & Min & 10,000 & 2 & 4 & 5 & 15 & 50 & 0.75 \\
\cline { 2 - 9 } & - & 4 & - & 8 & - & 75 & 1.35 \\
\hline
\end{tabular}

Table 6: Marshall Mix design results for all mixes.

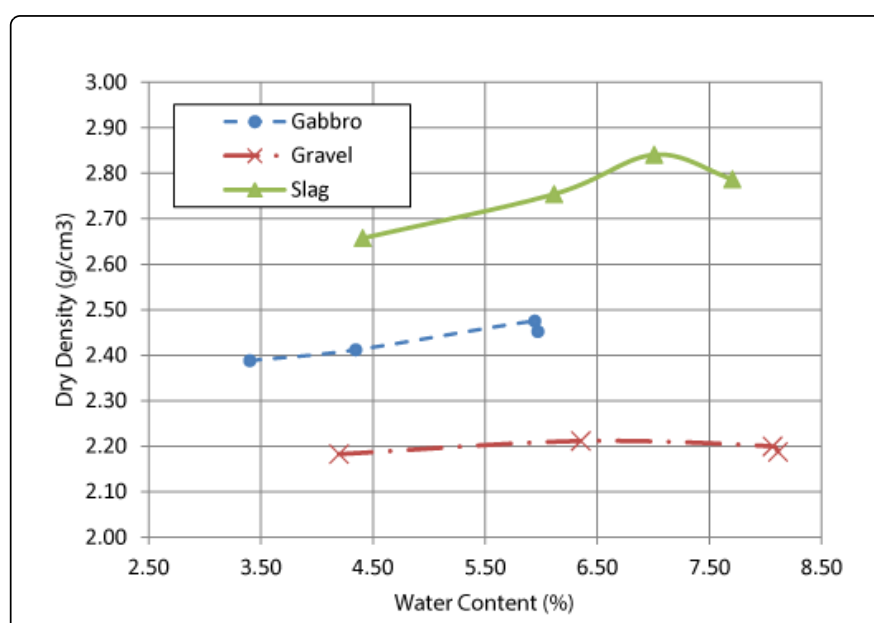

Figure 5: Modified proctor compaction results.

Figure 5 indicates that the optimum moisture contents for steel slag, gravel and gabbro aggregates are $7.0 \%, 6.4 \%$ and $5.9 \%$, respectively. The largest dry density was achieved in the steel slag aggregates.

CBR results: After determining the optimum moisture content for each aggregate type, the California Bearing Ratio (CBR) test was conducted. Two replicate samples were used for each aggregate type to determine the CBR values. No swelling was observed in the soaked samples. Table 7 presents the CBR values for different aggregate types used in this study. All aggregates satisfied the minimum CBR requirement of $80 \%$ specified in QCS-2010 for base and sub-base materials.

\begin{tabular}{|c|c|c|c|c|}
\hline & Steel Slag & Gravel & Gabbro & QCS-2010 \\
\hline CBR $(\%)$ & 239 & 143 & 129 & $\geq 80$ \\
\hline
\end{tabular}

Table 7: CBR results for soaked samples.

\section{Conclusions and Recommendations}

The main objective of this research work was to produce the fundamental data needed to establish the suitability of using local discarded materials, such as steel slag and gravel in roads construction (bases/sub-bases and hot mix asphalt concrete mixtures). 
Physical properties, such as Los Angeles abrasion, flakiness and elongation indices, soundness and sand equivalency values for steel slag, gravel and gabbro aggregates satisfied all criteria set forth in QCS-2010. Nevertheless, fine aggregates ofgravel did not satisfy the QCS soundness requirement. Based on the mixtures prepared and the data obtained in this work, steel slag and gravel aggregates have a promising potential to be used in hot mix asphalt concrete paving mixtures on Qatar highways, whether as an asphalt base course or as an asphalt wearing course.

In addition radiological properties were investigated and the results indicated that the use of high percentages of steel slag $(>20 \%)$ will easily meet the $\mathrm{H} 2$ requirement of $\leq 1.0$ for asphalt concrete road applications. Even for steel slag usage in certain asphalt concrete road applications close to populated and residential areas, it will be possible to meet the $\mathrm{H} 1$ requirement of $\leq 1.0$ if other mix design requirements and MOE recommendations are met.

It is also worth mentioning here that hot mix asphalt concrete (HMAC) mixtures can be designed using a variety of aggregate structures and blends that may result in different optimum asphalt contents and volumetric properties. Therefore, the results that were obtained here are meant to be an evidence of the possibility of using steel slag and gravel in HMAC mixtures and should not be treated as standard recipes for routine applications.

Steel slag and gravel physical properties, determined in the research project, met the QCS-2010 specifications' requirements for unbound materials. Also, based on compaction and California Bearing Ratio (CBR) test, steel slag and gravel aggregates have high CBR values that qualify their use in the base and sub-base layers.

Recommendations for further work include the construction of pilot field studies to establish the final validity for the construction use of steel slag and gravel. Such studies might encompass the construction of short road test sections, where steel slag and/or gravel could be used in the asphalt concrete base course, in the wearing (surface) course layer or as unbound aggregates in the base and subbase layers. Short- and long-term monitoring of such sections will be critical to establish construction practices as well as field performance under actual traffic and environmental (temperature, rain, humidity, etc.) conditions.

\section{Acknowledgments}

The research team gratefully acknowledges the financial support provided by Slag Aggregate Producer, under Qatar University (QU) Research Grant No. QUEX-CENG-SAP-12/13-1. In particular, special thanks are due to Mr. Devassy Baby of SAP, who was very supportive of the proposed research.

\section{References}

1. Taha RA, Sirin O, Al-Nuaimi N, Benyahia F (2013) Beneficial Utilization of Steel Slag and Gravel in Construction. Final Report, Slag Aggregates Producer.

2. ASTM D5106 (1991) Standard specification for steel aggregates for bituminous paving mixtures. ASTM International, USA.

3. Emery J (1984) Steel Slag Utilization in Asphalt Mixes. Proceedings. Canadian Technical Asphalt Association.

4. Collins RJ, Ciesielski SK (1994) Recycling and use of waste materials and by-products in highway construction. National Cooperative Highway Research Program, Synthesis of Highway Practice 199, Transportation Research Board, Washington DC, USA.

5. Recycled materials resource center (2013) User guidelines for byproducts and secondary use materials in pavement construction. Federal Highway Administration, USA.

6. Kandahl PS, Hoffman GL (1982) The Use of steel slag as bituminous concrete fine aggregate. Final report, Research project No. 79-26, Pennsylvania Department of Transportation, USA.

7. Hunt L, Boyle G, (2000) Steel slag in hot mix asphalt concrete. Final report, Report No. OR-RD-00-09, Oregon Department of Transportation, USA.

8. Xue Y, Wu S, Hou H, Zha J (2006) Experimental investigation of basic oxygen furnace slag used as aggregate in asphalt mixture. J Hazard Mater 138: 261-268.

9. Ahmedzade P, Sengoz B (2009) Evaluation of Steel Slag Coarse Aggregate in Hot Mix Asphalt Concrete. J Hazard Mater 165: 300-305.

10. BS 4987: Part 1 (1993) Coated macadam for roads and other paved areas. Part 1: Specification for constituent materials and for mixtures, British Standard, UK.

11. Gupta JD, Kneller WA, Tamirisa R, Skrzypezak-Jankun E (1994) Characterization of base and subbase iron and steel aggregates causing deposition of calcareous tufa in drains. Transportation research record, Washington DC, USA 1434: 8-16.

12. Aiba SA (2006) Utilization of steel slag aggregate for road bases. Journal of Testing and Evaluation 34.

13. Shen $\mathrm{W}$, Zhou M, Ma W, Hu J, Cai Z (2009) Investigation on the application of steel slag-fly ash-phosphogypsum solidified material as road base material. J Hazard Mater 164: 99-104.

14. Carl BC, Burn KN (1969) Building damage from expansive steel slag backfill. Journal of the Soil Mechanics and Foundations Division 95: 1325-1334.

15. Gupta JD, Kneller WA (1993) Precipitate potential of highway sub base aggregates. Report No. FHWA/OH-94/004, Ohio Department of Transportation, USA. 